\title{
ANTONI PŁOSZCZYNIEC*
}

\section{CZY SENS ŻYCIA JEST TYM SAMYM CO CEL ŻYCIA? ROZWAŻANIA AKSJOLOGICZNE}

Słowa kluczowe: sens życia, życie, obiektywizm aksjologiczny, Elzenberg, teleologia, cel

Keywords: meaning of life, life, axiological objectivism, Elzenberg, teleology, purpose

\section{Uwagi wstępne}

W artykule starano się odpowiedzieć na pytanie, czy sens życia i cel życia są ze sobą tożsame. Pojęcie ,sens życia” zawęża się do sensu określającego jednostkowe życie ludzkie (a nie np. życie gatunku lub wspólnoty) oraz stanowi rezultat ludzkiego działania. Tak pojęty sens życia określa się

* Antoni Płoszczyniec - absolwent Kolegium Międzywydziałowych Indywidualnych Studiów Humanistycznych i Społecznych Uniwersytetu Wrocławskiego, w ramach którego ukończył filozofię oraz dziennikarstwo i komunikację społeczną. Doktorant Instytutu Filozofii Uniwersytetu Wrocławskiego, pisze pracę doktorską o antropologii filozoficznej Henryka Elzenberga. Interesuje się filozofią kultury, antropologią filozoficzną, aksjologią, ontologią i historią polskiej filozofii. Publikował m.in. w „Hybris”, „Studia Philosophica Wratislaviensia” oraz „Archiwum Historii Filozofii i Myśli Społecznej”.

Address for correspondence: Antoni Płoszczyniec, University of Wrocław, Faculty of Social Sciences, Institute of Philosophy, ul. Koszarowa 3, 51-149 Wrocław. E-mail: antoniploszczyniec@gmail.com. 
w niniejszej pracy jako sens, który nadajemy sobie (resp. swojemu życiu). To oznacza, że w tekście nie wygłasza się żadnych twierdzeń na temat sensu życia pojmowanego jako coś wyznaczonego lub nadanego „odgórnie” człowiekowi przez coś lub kogoś. Nie stwierdza się ani nie zaprzecza obecności sensu określonego w poprzednim zdaniu - tym bardziej nie wyklucza się, że życie może być jednocześnie sensowne w obu znaczeniach.

Niniejsze dociekania traktują sens życia w kategoriach obiektywistycznych $^{1}$, jako cechę (w szerokim znaczeniu) życia niezależną od odczucia jego sensowności. To ostanie stanowi przedmiot badań psychologicznych (Przełęcki, 2002, s. 235). W artykule sformułowano stanowisko filozoficzne, które rozważa sens życia na gruncie obiektywizmu aksjologicznego, dystansując się od emotywizmu i subiektywizmu aksjologicznego.

Rozważeniu tytułowej kwestii służy szereg objaśnień, w których główną rolę odgrywa analiza pojęciowa i językowa. Celem analiz jest odróżnienie i uporządkowanie rozmaitych znaczeń pojęć i terminów oraz przede wszystkim eksplikacja takich pojęć życia i sensu, które będą mogły stanowić właściwy grunt do postawienia i rozstrzygnięcia pytania o tożsamość celu życia z sensem życia. Rozważy się także, czy wyróżnione pojęcia sensu stosują się do tego, co nazywamy „sensem życia”.

\section{Analiza pojęcia życia}

Celem niniejszego paragrafu jest odnalezienie takiego znaczenia słowa „życie”, które byłoby właściwe do orzekania o sensie, który można nadać sobie samemu. Punktem odniesienia analizy jest fragment monografii O szczęściu (1962), w którym Władysław Tatarkiewicz wskazuje trzy różne znaczenia. Praca ta wydaje się stosowna ze względu na bliskość felicytologii i zagadnienia sensu życia: „Aby człowiek mógł być zadowolony z życia,

${ }^{1}$ Przez obiektywizm aksjologiczny rozumiem stanowisko, według którego 1) istnieją wartości, które mają charakter własności lub cechy przedmiotu (por. Belknap, 1938, s. 30), resp. warstwy lub nadbudowy przedmiotu, oraz 2) sądy o wartościach (oceny) są zdaniami w sensie logicznym. Innymi słowy, według obiektywizmu aksjologicznego są takie wartości, które ani nie istnieją tylko w przeżyciach podmiotu, ani nie są cechami relacyjnymi, lecz są cechami samych przedmiotów, które przysługują im niezależnie od podmiotu, oraz o których można wygłaszać sądy prawdziwe lub fałszywe. 
jednym z najistotniejszych warunków jest, aby był przekonany, że ma ono jakiś sens, jakąś wartość" (Tatarkiewicz, 1962, s. 36).

Po pierwsze, termin ,życie” może oznaczać „,proces biologiczny dokonujący się w (...) organizmie od urodzenia aż do śmierci” (Tatarkiewicz, 1962, s. 35). Tak rozumiane życie jest czynnikiem konstytuującym tożsamość i ciągłość istnienia bytów ożywionych (w tym człowieka), jest sposobem ich istnienia. Ściśle rzecz biorąc, organiczne (resp. biologiczne) pojmowanie życia nie odpowiada poszukiwanemu znaczeniu sensu życia. Życie ludzkie bowiem ma tę specyficzną cechę, że człowiek może uprzedmiotowić swoje życie i zdystansować się wobec niego. Zrównanie życia ludzkiego do dzoe (greckie pojęcie życia wspólnego roślinom, zwierzętom i ludziom) jest nieadekwatne, ponieważ „Człowiek żyje o tyle, o ile w jakiśs sposób prowadzi swoje życie" (Plessner, 1994, s. 85) - to określenie unaocznia, dlaczego biologiczne znaczenie terminu, „życie" nie może być tym, które mamy na myśli mówiąc o nadawaniu własnemu życiu sensu. Człowiek może wprawdzie wpływać na biologiczne procesy własnego życia (np. podjąć leczenie lub zabić się), ale organicznie pojmowanemu życiu sensu nie nadajemy ${ }^{2}$. To przekonanie nie wyklucza, że życie w znaczeniu biologicznym w ogóle nie może mieć sensu - może bowiem być tak, że fakt czyjegoś organicznego trwania ma udział w realizacji Bożego Planu. Tego rodzaju odmiany sensu życia są poza niniejszymi rozważaniami.

Tatarkiewicz wskazuje inne znaczenie terminu ,życie”, mianowicie „proces psychologiczny dokonujący się w świadomości człowieka, zespół spostrzeżeń, wyobrażeń, uczuć, sądów, dążeń, które od urodzenia do śmierci przeszły przez jego świadomość" (Tatarkiewicz, 1962, s. 36). Takie rozumienie życia jest bliższe przedmiotowi niniejszego tekstu ze względu na związki sfery psychologicznej z aktami woli i wszelkimi dążnościami, co łączy się z nadawaniem sensu własnemu życiu. Niemniej, psychologiczne rozumienie życia uzależnia sens życia od subiektywnych stanów świadomości, przez co nie odpowiada określonemu w uwagach wstępnych filozoficznemu charakterowi dociekań. Jeśli wszelki sąd o sensie życia byłby sądem

2 Jest tak, ponieważ rozważane w niniejszym tekście pojęcie sensu życia jest zawężone do sensu, który w jakiś sposób nadajemy sobie i ma związek z naszymi działaniami, a życie rozumiane biologicznie nie odpowiada tej charakterystyce (można bowiem biologicznie trwać, nie dokonując żadnych działań, np. podczas śpiączki). Jak się zdaje, biologiczne trwanie jest fundamentem umożliwiającym człowiekowi działanie, a nie samym działaniem. 
o odczuciu sensu życia, to sprzeczna byłaby jakakolwiek próba pomyślenia, że pewien człowiek sądzi, że jego życie jest sensowne, i że jednocześnie, wbrew przekonaniom tego kogoś, jego życie sensu nie ma (lub vice versa). A skoro możemy tak pomyśleć bez żadnych przeszkód, to sąd „Moje życie ma sens” i ,Jestem przekonany (resp. czuję), że moje życie ma sens”, nie znaczą tego samego. Skoro oba zdania nie są równoznaczne, można domniemywać, że sens życia nie jest stanem mentalnym. Ponadto wydaje się, że życie określonego człowieka może mieć sens, mimo że w danej chwili nie jest tego świadomy, np. bo śpi, jest zakompleksiony lub jest w śpiączce.

Trzecie wyróżnione przez Tatarkiewicza znaczenie terminu ,życie” jest następujące:

„życie człowieka” to tyle, co zespół wszelkich procesów, w których brał udział i na które reagował od urodzenia do śmierci. W tym najczęściej znaczeniu mówimy, że szczęśliwy jest zadowolony z życia. Życie tak rozumiane jest zespołem zdarzeń dokonujących się nie tylko wewnątrz jego osoby psychofizycznej, ale także na zewnątrz niej. I to nawet takich zdarzeń, w których udział jego był bierny: do życia człowieka należy także diagnoza lekarska, która uratowała mu zdrowie; i uchwała instytucji, która powołała go na stanowisko; i wojna, w której nawet nie walczył, ale która zniszczyła mu dobytek; i pojawienie się książki, która oddziałała na jego poglądy; i śmierć innego człowieka, która pogrążyła go w smutku (Tatarkiewicz, 1962, s. 36).

Zaletą powyższego rozumienia terminu ,życie” jest uwypuklanie dynamicznych aspektów życia: wskazuje bowiem, że na jakość naszego życia wpływ ma to jak reagujemy na pewne zdarzenia i jak postępujemy wobec nich. Niewłaściwe natomiast wydaje się sformułowanie Tatarkiewicza, że życie to nie tylko zdarzenia znajdujące się ,wewnątrz” osoby, ale również na zewnątrz niej. Wojna nie jest częścią mojego życia, tak samo jak śmierć innego człowieka, diagnoza czy uchwała instytucji. „Częścią” mojego życia może być to, że w takim a takim czasie przebywałem w miejscu, w którym trwała wojna oraz to, że wobec konfliktu jakoś ustosunkowałem się (np. walczyłem, kolaborowałem, itp.). Śmierć innego człowieka również nie jest zdarzeniem z mojego życia, ale czyjaś śmierć może wpłynąć na moje życie i postępowanie. Innymi słowy: „elementem” mojego życia jest reakcja na pewne zdarzenie, stan rzeczy lub rzecz, postępowanie wobec nich, zajęcie określonej postawy, a nie zdarzenie, stan rzeczy lub rzecz, wobec której jakoś się zachowuję. Tym, co łączy reakcję, zajęcie postawy 
i postępowanie jest okoliczność, że każde z nich dokonuje się dzięki aktom spełnianym przez człowieka (np. akt decyzji kolaborowania z najeźdźcą w obliczu wybuchu wojny; akt rezygnacji z wycieczki z powodu śmierci przyjaciela). Życie $w$ tym znaczeniu byłoby zatem uporządkowanym zbiorem aktów ${ }^{3}$ dokonywanych przez daną osobę od jej urodzin aż do śmierci ${ }^{4}$. Takie rozumienie życia wydaje się najwłaściwsze do rozważenia sensu życia i można je nazwać ,aktowym pojęciem życia”.

Należy jeszcze skomentować pewien wątek obecny w ostatnim wyróżnionym przez Tatarkiewicza sposobie rozumienia życia. Nie ma w nim ostrej granicy między moim życiem a czyimś, ponieważ „«Moje» życie jest tak samo «moje», jak «moje» miasto lub «moja» ojczyzna: co najwyżej tylko część jego należy wyłącznie do mnie" (Tatarkiewicz, 1962, s. 36). Procesy, w których ktoś bierze udział i na które reaguje, często są dzielone z innymi ludźmi. Choć można przyjąć, że człowiek jest istotą społeczną i że jego życie w znacznej mierze jest życiem społecznym, to pomimo problematyczności wskazania granicy między moim a cudzym życiem, intuicyjnie pojmujemy, że istnieje radykalny rozdział między moim życiem a cudzym. Aktowe pojęcie życia pozwala lepiej zrozumieć tę przepaść: podmiot ma uprzywilejowany, pierwszoosobowy dostęp do dokonywanych przez siebie aktów, jest ich wyłącznym spełniaczem. Istnienie osoby niejako „rozpościera się” na spełnianych przez nią aktach. Jeżeli ta sama wojna zniszczyła dobytek Piotra i Pawła, to akt rozpaczy Piotra nie jest tym samym aktem co rozpacz Pawła.

Akty stanowią o odrębności ontologicznej podmiotów żyjących, co pozwala na odróżnienie sensu życia indywidualnej osoby od pojawiającego się w pismach Czeżowskiego społecznego pojęcia sensu życia. Autor Filozofii na rozdrożu określa je następująco: jeżeli społeczeństwo tworzy dorzeczną, sensowną całość, to życie uczestniczące w takim społeczeństwie

3 Powiedzieć, że życie stanowi zbiór aktów, to powiedzieć za mało, ponieważ między poszczególnymi aktami zachodzą związki o charakterze porządku, np. zwolnić się z pracy można tylko, gdy wcześniej tę pracę się podjęło. Poprzestańmy na tym ogólnym określeniu, bez wcześniejszego przesądzania, jakiej natury jest ów porządek. Niewykluczone, że poszczególne grupy aktów różnią się co do sposobu uporządkowania lub nawet, że te same akty występują w różnych porządkach.

${ }^{4}$ W przypadku człowieka w stanie wegetatywnym wciąż mamy do czynienia z życiem, jednakże byłoby to życie w znaczeniu biologicznym, ono zaś nie wydaje się stosowne do charakterystyki sensu życia jako czegoś, co nadajemy sobie samym. 
i realizujące postawione przez społeczeństwo zadania i funkcje ma sens społeczny (Czeżowski, 1989b, s. 176-177).

Sens życia indywidualnego nie jest tym samym, co sens życia społecznego. Można bez sprzeczności pomyśleć, że człowiek spełnia wyznaczone przez społeczeństwo zadanie (dzięki czemu jego życie miałoby społeczny sens) i że jednocześnie życie tego człowieka ujętego in individuo byłoby pozbawione sensu lub byłoby sensowne w dużo mniejszym stopniu od sensu społecznego. Lekarz wypełniający swoje obowiązki, wedle Czeżowskiego, byłby sensownie żyjącym, ale przecież ten sam lekarz może prowadzić życie - jako takie - pozbawione sensu.

Według Czeżowskiego „każda jednostka ma wyznaczony przez zawód lub stanowisko społeczne zakres działania, który nadaje sens jego życiu" (Czeżowski, 1989b, s. 177). Uchylanie się od tych zadań oraz uczestnictwo we wspólnocie przypadkowej i zdezorganizowanej, anarchicznej, pozbawia życie społecznego sensu lub nie daje go (Czeżowski, 1989c, s. 182). Jeżeli sens życia byłby istotnym dobrem per se, a nie tylko dobrem dla tego, czyje to życie, to żywot bandycki, oparty na zadawaniu gwałtu bliźnim, nie jest sensowny. Ale ten sam bandyta może realizować sens społeczny, jeżeli spełniałby zadania wyznaczone przez złą, bandycką wspólnotę. To oznacza, że treści sensu indywidualnego i społecznego nie pokrywają się ze sobą, a zatem jest możliwy przypadek, że życie człowieka jest sensowne społecznie, lecz nie indywidualnie.

Z drugiej strony, można pomyśleć sobie człowieka, który jest odludkiem, samotnikiem, a nawet pustelnikiem i którego życie ma sens indywidualny, mimo że nie zostawia wyraźnych (lub żadnych) śladów w społeczeństwie - byłoby to zatem życie indywidualnie sensowne, lecz pozbawione sensu społecznego. Ponadto, ktoś może prowadzić indywidualnie sensowne życie w złej wspólnocie, a nawet żyć sensownie, zakłócając jej funkcjonowanie (np. niemieccy opozycjoniści w Trzeciej Rzeszy).

Rozważmy na koniec wariant, w którym życie człowieka jest jednocześnie sensowne indywidualnie i społecznie. Nie znaczy to, że treść obu sensów jest identyczna, ponieważ można osobno rozpatrywać sensowność życia człowieka, który dokonał czegoś, i osobno społeczne skutki jego działania (np. stworzenie wynalazku lub odkrycie naukowe), które mogą po latach zmienić swój charakter: Fritz Haber stworzył cyklon B jako środek do dezynsekcji i dezynfekcji, lecz jego wynalazek znalazł inne zastosowanie. 
Wydaje się, że sens indywidualny jest pierwotny, a społeczny - wtórny, ponieważ indywidualny sens życia jest niezależny od społecznego, a społeczne skutki naszych działań są wtórne względem aktów powodujących je. Społecznik prowadzący działalność charytatywną prowadzi dobre życie ${ }^{5}$, przy czym jeżeli przyjmuje się aktowe pojęcie życia, należy uznać, że taki człowiek realizuje dobre akty. Aksjotyczną jakość danego aktu określa się nie tylko na podstawie samej treści i ukierunkowania aktu, ale również przez charakterystykę okoliczności i skutków zamierzonych przez akt. Wszak mimo tego, że pomaganie innym jako takie jest dobre, to konkretny akt pomocy wcale nie musi być dobry, bo można pomóc niewłaściwej osobie, w niewłaściwy sposób, w nieodpowiednim czasie i/lub miejscu. Pozostawiając na boku kwestię zakresu odpowiedzialności człowieka za skutki swoich działań, pozostaje faktem, że część zdarzeń i stanów rzeczy ma źródło w aktach woli człowieka. Nie ma społecznych reperkusji działania indywidualnego człowieka bez działania tego człowieka - nawet jeśli działa jako przedstawiciel grupy społecznej - o ile jego działanie w ogóle ma jakieś społeczne konsekwencje. Na tej podstawie można uznać, że społeczny sens życia jest czymś odrębnym i wtórnym względem indywidualnego sensu życia.

Należy podkreślić, że uwarunkowanie sensu społecznego przez sens indywidualny i nadawany sobie samemu może nie być uprawnione przy rozumieniu sensu życia ludzkiego jako czegoś, co człowiek „,znajduje” lub „zastaje”.

\section{Odmiany pojęcia sensu}

Po omówieniu pojęcia życia można wskazać odmiany pojęcia sensu. Posłuży to rozpatrzeniu, czy dane pojęcie charakteryzuje sens życia, czy nie.

Pierwszą odmianę stanowi semiotyczne pojęcie sensu. Właściwie jest to nie tyle odmiana, co grupa odmian, których cechą wspólną jest charakteryzowanie sensu przez pojęcie znaku i znaczenia. Wyróżniamy tu sens logiczny, kulturowy, językowy i poznawczy.

5 Dobre życie można realizować na wiele sposobów, a życie poświęcone działalności społecznej jest, jak się zdaje, jednym z takich sposobów. 
Sensem logicznym jest elementarna (logiczna) treść wyrażenia lub zdania. Na gruncie logiki sensowne są zdania oznajmiające, którym można przypisać wartość logiczną prawdy lub fałszu. Rozkaz „Posprzątaj pokój!” jest pozbawiony logicznego sensu, bo nie jest zdaniem oznajmującym.

Sens kulturowy stanowi znaczenie lub zespół znaczeń nadawanych przez członków kultury pewnym przedmiotom, które znaczą coś specyficznego dla członków owej kultury. Przykład: znak Polski Walczącej jest dla Polaków symbolem walki o niepodległość. Znaczenie kulturowe mają nie tylko symbole, ale również rzeczy, obyczaje, rytuały i miejsca (np. jako cel pielgrzymek).

Sens językowy jest pokrewny sensowi logicznemu. Sensowne językowo są wszystkie wyrażenia i zbudowane na ich podstawie zdania, które są uznawane wśród użytkowników danego języka. Na przykład, w języku polskim zdanie „Janek ma pieniądze” i słowo ,pieniądz” ma sens, ale „Jankom pieniądzem drzewu” i ,szelałama” sensu nie ma. Sens językowy jest relatywizowany do języka.

Sens poznawczy stanowią wszystkie doznania, pojęcia, obrazy, wyobrażenia i koncepcje, które służą reprezentowaniu poznawanej rzeczywistości. Sensem poznawczym jest pewien mniej lub bardziej złożony psychiczny „obiekt” w poznawczej przestrzeni mentalnej podmiotu, pełniący funkcje semiotyczne przez organizację globalnego (ogólnego) bądź lokalnego (zrelatywizowanego do „tu i teraz”) stanu wiedzy podmiotu.

Przedstawione wyżej odmiany sensu semiotycznego nie stanowią pojęcia sensu życia. Życie sensowne zasługuje na miano „znaczącego”, lecz „znaczące” w tym kontekście jest synonimem „doniosłości”, „wartościowości”, ,ważkości” i jako takie nie ma charakteru semiotycznego. Nawet jeśli uzna się, że okoliczność, iż czyjeś życie ma sens, pełni jakąś rolę semiotyczną (np. wskazuje na istnienie Opatrzności), to sama sensowność życia nie polega na pełnieniu funkcji semiotycznych.

Dwie kolejne odmiany mogą odpowiadać sensowi życia. Jedna z nich to sens teleologiczny. Używając określenia Elzenberga, teleologicznie „[s]ensowne jest, ma sens to, co celowe, wewnętrznie albo zewnętrznie: postępek, akt zmierzający do czegoś - układ celowo skonstruowany" (Elzenberg, 1991a, s. 338). Teleologiczne pojęcie sensu przypisuje się przede wszystkim działaniom: jeżeli działanie i przedsięwzięte środki są stosowne do osiągnięcia celu, owo działanie jest teleologicznie sensowne. Akty woli również są teleologicznie sensowne: przykładowo, akt roztropności 
(gr. phronesis) ma teleologiczny sens, ponieważ pozwala na dostrzeżenie stosownego rozwiązania problemu praktycznego. Sensowne teleologicznie są przedmioty, o ile stanowią złożone całości o budowie uporządkowanej ze względu na cel, jak części roweru ze względu na jazdę. Teleologicznie sensowne są również zbiory przedmiotów tworzące celowo uporządkowane układy. Jeśli współpraca i podział obowiązków w grupie ma służyć realizacji zadania, to mamy do czynienia z teleologicznie sensownym zespołem ludzi.

Reasumując, sens teleologiczny jest uzasadnieniem ze względu na cel. Zauważyć trzeba, że jeśli sens życia jest dobrem, to sens teleologiczny, jeśli stanowi o sensie życia, również musi być charakteryzowany jako dobro. Sens teleologiczny ten warunek spełnia, ponieważ jeśli stanowi uzasadnienie czegoś ze względu na cel, to stopień uzasadnienia jest miarą wartościowego charakteru rzeczy, której przypisujemy sens (np. mając na celu wbicie gwoździa w ścianę, młotek jest lepszy od żelazka).

Trzeba odróżnić dwie odmiany teleologicznego pojęcia sensu - nie każdy bowiem cel jest czymś, co człowiek nadaje własnemu życiu. Istnieje spora grupa celów rozumianych jako to, do czego ,jakaś rzecz lub stan rzeczy jest przeznaczona (czemu służy)" (Elzenberg, 1991b, s. 377), odmiennych od celów nadawanych autonomicznie. Na przykład zderzaki są przeznaczone do łagodzenia kolizji i to stanowi cel zderzaków. Być może życie ludzkie ma cel, który polega na wypełnianiu przeznaczonego mu zadania, ale nawet jeśli taki cel jest, nie może stanowić o sensie jako czymś nadawanym sobie samemu.

Należy jeszcze rozpatrzyć aksjologiczne pojęcie sensu. Według Elzenberga stosuje się ono do istnienia rzeczy lub osób wartościowych (Elzenberg, 1991a, s. 341). Jeżeli Kolumna Zygmunta jest wartościowa, to jej istnienie jest sensowne. Podobnie sensowne jest istnienie sprawiedliwego sędziego, mędrca itd. Na tej podstawie można stwierdzić pochodność sensu od wartości: jeżeli jakiś przedmiot jest wartościowy, to istnienie tego przedmiotu jest aksjologicznie sensowne. „Wartość stwarza sens, nadaje sens; sens płynie z wartości” (Elzenberg, 1991a, s. 345). Z powyższej charakterystyki wynika, że aksjologiczne pojęcie sensu może odpowiadać temu sensowi życia, który człowiek nadaje sobie samemu. Ale można pomyśleć również aksjologiczny sens, który człowiek samemu sobie nie nadaje: samo umieszczenie w świecie, którego istnienie ma sens, czyni życie poniekąd sensownym (Elzenberg, 1991a, s. 345-346). 
Wobec aksjologicznego pojęcia sensu można zadać pytanie, w których przedmiotach może tkwić ostateczna racja aksjologiczna warunkująca sensowność istnienia danego przedmiotu. W zasadzie można powiedzieć, że racja może tkwić albo w samym przedmiocie, którego istnienie jest sensowne, albo poza nim. Pierwszy wariant można unaocznić następująco: jeśli sprawiedliwość czyni człowieka dobrym, a więc wartościowym, to istnienie danego człowieka jest sensowne, przy czym wartość nadająca mu sens przysługuje samemu człowiekowi, a nie czemuś poza nim. Wedle drugiego wariantu sens wciąż jest pochodny od wartości, lecz wartość ostatecznie nadająca sens życiu pewnego człowieka nie jest wartością, którą przypisujemy tej właśnie osobie, lecz komuś lub czemuś innemu. Przykładowo, jeżeli obraz jest piękny i wartościowy, wtedy jego twórca sam staje się wartościowy, ale pośrednio, ze względu na obraz i jako jego twórca. Drugi wariant dobrze oddaje pojęcie wartości pochodnej, które za Elzenbergiem rozumie się następująco: ,A posiada wartość pochodną, jeżeli jednym z warunków jego wartości jest wartość jakiegoś nie- $A$; albo: Przedmiot posiada wartość pochodną, jeżeli jednym z warunków jego wartości jest wartość jakiegoś nie- $A$ " (Hostyński, 1999, s. 58). To pozwala stwierdzić, że przedmiot $A$ ma wartość ostateczną, jeżeli nie ma takiego nie- $A$, które jest warunkiem wartościowości $A$.

Jest możliwe, aby jedna rzecz otrzymywała sens z więcej niż jednego źródła: np. artysta, który tworzy wartościowe dzieła, sam staje się pochodnie wartościowy, ale ten sam artysta może być sprawiedliwym człowiekiem, dzięki czemu wartość nadająca sens przysługuje jemu samemu. W każdym razie istotne jest, że sens jest pochodny od wartości, a wartość staje się racją sensowności życia. To pozwala uznać, że sens aksjologiczny ,,jest to aksjologiczne uzasadnienie istnienia czegoś” (Elzenberg, 1991b, s. 378).

\section{Sens życia a cel życia}

Teraz należy przystąpić do próby odpowiedzi na pytanie, czy sens życia jest tym samym, co cel życia. Przez ,cel życia” rozumiem cel całościowo organizujący życie ludzkie, który ze względu na swoje źródło, rolę lub ogólność stanowi coś, co w zasadniczy sposób charakteryzuje dane życie. 
Wydawałoby się, że sens życia i cel życia oznaczają to samo. Z jednej strony mamy do czynienia $\mathrm{z}$ wieloma obiegowymi skojarzeniami, które utożsamiają oba pojęcia. Ma to swoje źródło w tym, że niejednokrotnie pytania o sens życia są formułowane w sposób dający się zinterpretować teleologicznie, np. ,„ро co człowiek żyje?”; „dla czego żyje?” itp. Ponadto wśród wielu polskich myślicieli przeważa koncepcja, że sens życia to innymi słowy cel życia. Takie stanowisko można przypisać m.in. Kołakowskiemu (przynajmniej we wczesnych publikacjach) (1957, s. 176), Bocheńskiemu (1993, s. 10) i Krąpcowi (1991, s. 261).

Można jednak przedstawić argumenty za tym, że sens życia to coś innego od celu życia. Wpierw należy zauważyć wbrew Kołakowskiemu, że nieprawdą jest, że „sens życia i cel życia oznaczają to samo” (Kołakowski, 1957, s. 176), ponieważ oba pojęcia nie są równoważne. Można stwierdzić tylko „że cel nadaje życiu sens” (Elzenberg, 1991b, s. 377). Ponadto zwróćmy uwagę, że życie człowieka może być wartościowe również wtedy, gdy nie dąży do celu. „Życie dążące do świętości jest przypuszczalnie sensowne, ale życie święte jest chyba co najmniej równie sensowne" (Elzenberg, 1991b, s. 377).

Główną przesłanką dociekań nad sensem życia jest to, że sens życia jest dobrem, a właściwie, że jest dobrem per se: pożądamy sensu życia ze względu na niego samego, a nie ze względu na coś innego. Co więcej, nie ma czegoś takiego jak zły, niewłaściwy, ujemny sens życia, ,,przeciwsens”. Właściwym przeciwieństwem sensu życia jest brak sensu, bezsens (Elzenberg, 1991a, s. 343). Używając metafory liczbowej: stosunek między wartością dodatnią (np. dobrem) a ujemną (np. złem) jest jak stosunek liczby dodatniej do ujemnej; sens zaś do bezsensu ma się jak liczba dodatnia do zera. Sens życia nie dopuszcza swojej przeciwnej odmiany, wśród celów zaś możemy spotkać złe cele. Ta okoliczność stanowi o zasadniczej różnicy między sensem życia a celem życia. Ponadto, trudności nasilają się przy czysto teleologicznym rozpatrywaniu sensu, ponieważ oznacza to abstrahowanie od wartości celu (Elzenberg, 1991a, s. 338), co stoi w konflikcie z przesłanką, że sens życia jest dobrem.

Gdyby sens życia był tym samym co cel życia, albo gdyby cel nadawał życiu sens, to nie byłoby złych celów życiowych, bo skoro sens życia ma być istotnym dobrem per se, to nie może wynikać ze zła. Niektórzy ludzie zaś kierują swoim życiem podług złych celów, co pozwala stwierdzić, że 
sens życia jest czymś innym od celu życia ${ }^{6}$. Chęć zemsty dostarcza niekiedy silnych motywów by żyć, jednak wydaje się, że życie dla zemsty jest złym życiem. Nawet ostateczna pomsta na wrogach może nie dać ukojenia, co unaocznia Edmund Dantes, alias hrabia Monte Christo. Zresztą nawet gdyby zemsta dawała ukojenie, to można zasadnie wątpić, czy krwawa wendetta jest moralnie dobra. Drastycznym i dobitnym przykładem nadawania życiu złych celów jest Aleksandr Piczuszkin, rosyjski seryjny morderca znany jako „Szachownicowy Zabójca”, którego przydomek pochodzi stąd, że po każdym zabójstwie umieszczał numerek na polu szachownicy (chciał w ten sposób zapełnić wszystkie pola) ${ }^{7}$.

Nie tylko złe cele przeczą utożsamieniu sensu życia i celu życia. Poza dobrymi i złymi celami istnieją jeszcze cele miałkie, liche, pozbawione doniosłości, trywialne. Nie są wprawdzie złe ( $\mathrm{tj}$. niegodziwe, niemoralne itd.), ale nie są też dobre: „Wszak trudno zgodzić się, że ma sens życie dziwaka, który wszystkie swe wysiłki kieruje ku zaspokojeniu manii kolekcjonowania rzeczy bezwartościowych" (Czeżowski, 1989a, s. 172) ${ }^{8}$. Księga Rekordów Guinnessa informuje nas o wielu nie-dobrych celach życiowych: ażeby zapisać się w historii ustanawia się rekordy w takich kategoriach, jak największa liczba słomek do napojów trzymanych w ustach, najwięcej założonych naraz t-shirtów, najwięcej butelek otwartych czołem itd. Można zasadnie wątpić, czy cele podobnego rodzaju w istocie nadają życiu sens, a nawet jeśli nadawałyby, to - w porównaniu z innymi życiowymi celami - raczej mniej sensu.

Poza złymi i nie-dobrymi celami, które odrzucono jako cele nadające życiu sens, są cele dobre, szlachetne i dodatnio wartościowe. Jednakże odwołanie się do tej grupy celów nie uzasadnia utożsamienia sensu życia z celem życia, ponieważ otwarte pozostaje pytanie, czy dobry cel nadaje życiu sens

${ }^{6}$ Przy psychologicznym rozumieniu sensu życia złe cele jak najbardziej mogą czynić życie sensownym. Niemniej, tak rozumiany sens jest poza przedmiotem rozważań. Ponadto, jeżeli sens życia jest dobrem per se, to nie może wynikać ze złych działań.

7 Piczuszkin miał stwierdzić w sądzie, że po zapełnieniu szachownicy zabijałby dalej, lecz nie wpływa to na argument, skoro stawiał sobie za cel zabijanie ludzi.

${ }^{8}$ Nie znaczy to, że życie poświęcone kolekcjonowaniu czegoś w ogóle nie ma wartości - Czeżowski krytycznie wypowiada się wyłącznie o zaspokajaniu manii zbierania „rzeczy bezwartościowych”. Jeżeli kolekcjonowane przedmioty są wartościowe (w sensie pozaekonomicznym, ,pozamaterialnym”), to również zbieranie owych przedmiotów jest wartościowe. 
dlatego, że jest dobry, czy dlatego, że jest celem. Jeśli wybierzemy pierwszy człon alternatywy, wtedy sens życia bardziej wiązałby się z aksjologicznym, a nie teleologicznym pojęciem sensu. Z kolei jeśli uznamy drugi człon, natrafimy na wcześniejsze wątpliwości dotyczące czysto teleologicznego charakteryzowania sensu życia. W obu więc przypadkach nie wydaje się słuszne twierdzenie, że sens życia jest tym samym, co cel życia.

Można jednak stwierdzić, że powyższe rozumowanie opiera się na fałszywej alternatywie. Dobry cel nadaje życiu sens nie dlatego, że jest dobry, ani dlatego, że jest celem, lecz dlatego, że jest takim dobrem, które stanowi cel; że jest dobrem o charakterze celu. Ta odpowiedź ma wspierać uznanie teleologicznego pojęcia sensu za odpowiadające pojęciu sensu życia, bo gdyby owo dobro nie było celem, sens życiu nie zostałby nadany. Wbrew temu zauważmy, że okoliczność, czy wartość jest celem czy nie, jest dla wartości indyferentna (Zwoliński, 1974, s. 255-256). Na gruncie obiektywizmu aksjologicznego przedmioty są wartościowe nawet wtedy, gdy ich cenność nie została rozpoznana. Życie człowieka jest opisywalne w znacznej mierze w kategoriach teleologicznych, stąd przy rozważaniach o sensie życia, który człowiek sam sobie nadaje, nie da się zupełnie abstrahować od kategorii celu. Ale z tego, że bez stawiania sobie celów życie człowieka nie byłoby sensowne, nie wynika, że sens życia ma charakter celu. Można bowiem uznać ujmowanie wartości jako celu za warunek realizacji tej wartości. Ale realizacja pewnej wartości jest aksjologicznie in plus o tyle, o ile to, co zostaje realizowane, samo jest aksjologicznie dodatnie. W takim razie dodatni charakter teleologicznego ujmowania pewnej wartości jest uwarunkowany przez dodatni charakter tego, co jest ujmowane jako cel. Pozwala to przyjąć, że wspomniana wyżej alternatywa nie jest fałszywa, bo ostatecznie teleologiczne ujęcie wartości może być cenne tylko ze względu na to, czego jest ujęciem, co umacnia twierdzenie, że to aksjologiczne pojęcie sensu opisuje sens życia.

Sensowne teleologicznie jest to, co służy celowi, tzn. jest uzasadnione ze względu na cel. Zapytać można: czy cel sam uzasadnia się teleologicznie, czy nie? Jeśli tak, to musi istnieć cel celu, następnie cel celu celu itd., przez co popadamy w regressus ad infinitum. A skoro cel nie może zostać ostatecznie uzasadniony w sposób teleologiczny, to w przypadku dysjunkcji ,,albo teleologiczne, albo aksjologiczne", należy uznać, że cel ma uzasadnienie aksjologiczne. Zauważmy, że aksjologiczne pojęcie sensu jest odporne na 
zarzut regresu w nieskończoność, bo regres przerywa wartość ostateczna, cenna ze względu na samą siebie, stanowiąca zasadę nadającą życiu sens.

Na gruncie aksjologicznej koncepcji sensu to wartość stanowi ostateczne źródło sensu, to z niej „płynie” sens. To, że coś ma sens, że w ogóle jest sensowne, na gruncie obiektywistycznej koncepcji wartości i aksjologicznego pojęcia sensu zawdzięczamy wartościom, a nie arbitralnemu aktowi woli. Skoro tak, to w jakim znaczeniu można w kontekście powyższych założeń mówić o nadawaniu sensu życia sobie? Skoro istotnym elementem ludzkiego zachowywania się i życia jest kierowanie się celami, to udział celu i woli w nadawaniu sensu własnemu życiu polegałby na tym, że wola dąży do tego, co wartościowe. „«Nadaje» się go [tj. sens - A.P.] życiu tylko w tym znaczeniu, że się dąży do celów wartościowych raczej niż do innych" (Elzenberg, 1991b, s. 379). Sens ostatecznie pochodzi od wartości, ale dopiero ukierunkowanie woli oraz działanie umożliwia usensowienie życia przez wartość. Metaforycznie: gdy człowiekowi jest zimno i zbliży się do rozpalonego pieca, to piec stanowi właściwą przyczynę ogrzania się człowieka. Kierując się w stronę pieca człowiek jedynie umożliwia ogrzanie się. Samym aktem woli człowiek nie ogrzeje się - potrzeba do tego jeszcze rozpalonego pieca.

Na gruncie aksjologicznego pojęcia sensu jest miejsce dla celów, lecz tylko jako podporządkowanych wartościom. Jeśli życie jest sposobem istnienia człowieka, to na gruncie aksjologicznego pojęcia sensu, sens życia polega na tym, że życie jest wartościowe i że po uwzględnieniu wagi czynów jest w nim więcej aktów wartościowych dodatnio niż ujemnie ${ }^{9}$. Można wobec tego zaoponować i stwierdzić, że z sensem życia istotnie wiąże się pewna dowolność i arbitralność decyzji: jedna osoba spełnia się jako artysta, druga jako naukowiec, trzecia jako społecznik. Życie ludzkie miałoby sens dlatego, że człowiek nadaje sobie takie cele i wartości jakie chce, a poczucie samorealizacji (rozumianej w duchu psychologii humanistycznej) uwiarygadnia twierdzenie o arbitralnym i subiektywnym charakterze sensu życia. Można zgodzić się z tym, że w sensie życia jest obecny pewien moment dowolności, pytanie tylko, jak go zinterpretować. Wpierw zauważmy, że obecność samorealizacji nie jest dostatecznym argumentem za subiektywnością sensu

9 Jak się zdaje, sens życia nie jest po prostu ilościową przewagą dobrych aktów nad złymi, ponieważ trzeba jeszcze „oszacować wagę” tych aktów. Ta okoliczność wskazuje, że sensowność życia jest stopniowalna, a nie ,zero-jedynkowa”. 
życia. Z tego, że jakiś uczynek oceniamy jako wartościowy, nie wynika, że taki w rzeczywistości jest. Jeśli przyjmujemy obiektywizm aksjologiczny wraz z aksjologicznym pojęciem sensu, to możliwa jest sytuacja, że ktoś mylnie uważa swoje życie za sensowne (Przełęcki, 2002, s. 235).

Dalej, należy zauważyć, że w sferze wartości jest pewna swoboda wyboru, którym wartościom się oddamy: jeden może spełnić się jako aktor, drugi jako filozof, trzeci jako społecznik. Nie ma obowiązku, aby każdy był aktorem, filozofem i społecznikiem. Ale z okoliczności, że oddawanie się nauce, sztuce i szerzeniu pomocy nadaje życiu sens, nie wynika, że arbitralnie ustanawiamy owe sfery jako wartościowe - one wartościowe już są i stanowią źródło sensu. Samo pomaganie ludziom, uprawianie nauki i sztuki jeszcze nie czyni życia sensownym, ponieważ te rzeczy, jakkolwiek są dobre, należy jeszcze dobrze wykonywać. Doza arbitralności w pojęciu sensu życia polega na tym, że mamy swobodę w wyborze wartościowych dziedzin, którym się oddamy ${ }^{10}$. Jeśli mogę równie dobrze zostać artystą jak filozofem, to decyzja, że zostanę tym lub tamtym (albo jednym i drugim) jest w pewnym znaczeniu arbitralna, lecz nadawanie życiu sensu polegałoby wciąż na tym, że wola kieruje się do sfery wartościowej, sensowność życia zaś wciąż pochodziłaby od wartości, nie od samego aktu woli. „«Nadawanie» życiu sensu (...); w tym znaczeniu, że się dociera do wartości i dąży do wartościowych celów, a one z kolei «nadają» sens życiu” (Elzenberg, 1991b, s. 378).

Wydaje się również, że traktowanie sensu życia czysto teleologiczniei co za tym idzie, arbitralnie - pozbawia go cenności. Skoro domniemywa się, że sens stanowi dobro per se, wtedy jego arbitralizacja czyni sens życia mniej wartościowym w tym znaczeniu, że traciłby charakter czegoś uzasadnionego. „Są cele stanowione dowolnie. Jest to wtedy czysta konwencja; to wypełnia życie, ale nie nadaje mu sensu. To tak jak wymyślanie gier konwencjonalnych: raz się gra w szachy, drugi raz w halmę - i całe życie jest taką grą. (Celem jest wygrać partię w czysto konwencjonalnej grze)" (Elzenberg, 1991b, s. 378).

${ }_{10}$ Wyjątek mogą stanowić niektóre wartości moralne, które mają swoiste aksjologiczne „,brzemię” wynikające z ich naruszania: wszak bycie złym (böse) człowiekiem jest o wiele gorsze niż bycie złym (schlecht) artystą lub filozofem. Napisano „niektóre”, ponieważ wydaje się, że wśród wartości moralnych są również wartości supraordynaryjne, które nie stanowią przedmiotu powszechnego obowiązywania, np. bohaterstwo. 


\section{Wnioski}

Odpowiedź na pytanie o tożsamość celu życia i sensu życia okazała się przecząca. Czysto teleologiczna koncepcja sensu życia nie czyni życia uzasadnionym i czyni z sensu życia coś arbitralnego. Głównym argumentem jest okoliczność, że cele, które stawiamy życiu, same domagają się aksjologicznego uzasadnienia: sens życia jest pewnym dobrem, którego złe i miałkie cele nie mogą nadać. Dobre cele umożliwiają nadanie życiu sensu, lecz dokonuje się to nie dzięki celowemu charakterowi czegoś, lecz ze względu na wartość celu. Tym samym teleologiczna koncepcja sensu życia odwołuje się do aksjologicznego pojęcia sensu, które można wskazać jako pojęcie, nie tylko charakteryzujące sens życia, ale również wyjaśniające, w jakim znaczeniu można mówić o nadawaniu sensu własnemu życiu: w tym mianowicie, że raczej dąży się do tego, co wartościowe, niż bezwartościowe lub przeciwwartościowe.

Na koniec zauważmy, że aksjologiczna koncepcja sensu życia pozwala twierdzić, że śmierć nie przekreśla ani nie unieważnia sensowności życia. Często bowiem, zwłaszcza w filozofii egzystencjalistycznej (np. u Sartre’a), traktuje się życie jako ciąg projektów, gdzie o sensie życia można mówić o tyle, o ile zachodzi projektowanie. Śmierć, jako kres istnienia jednostki, niweczy nie tylko możliwość projektowania, ale i sens życia (Bocheński 1993, s. 17). Niemniej, jeżeli wartości istnieją obiektywnie i oceny mogą mieć wartość logiczną oraz jeżeli prawdą jest, że życie danego człowieka miało sens, to fakt, że ten człowiek obecnie nie żyje, nie wpływa na sensowność jego życia. Jeśli sąd „3 V 2016 o $13^{00}$ w Głogowie było $18^{\circ} \mathrm{C}^{\prime}$ był prawdziwy, będzie prawdziwy również za 100 lat, nawet jeśli Głogów przestanie istnieć lub nikt nie będzie pamiętał o tym, jaka była wtedy temperatura. Per analogiam, jeśli prawdą jest, że pewna jednostka żyła sensownie, to sąd będzie prawdziwy również wtedy, gdy nikt nie będzie o niej pamiętał (Czeżowski, 1989, s. 174).

\section{Bibliografia}

Belknap, G.N. (1938). Objective Value. The Journal of Philosophy, 35 (2), 29-39.

Bocheński, J.M. (1993). O sensie życia. W: J.M. Bocheński, Sens życia i inne eseje (s. 7-22). Kraków: Philed. 
Czeżowski, T. (1989a). Jak rozumieć „,sens życia”. W: T. Czeżowski, Pisma z etyki i teorii wartości (s. 171-175). Wrocław: Ossolineum.

Czeżowski, T. (1989b). Sens i wartość życia (1). W: T. Czeżowski, Pisma z etyki i teorii wartości (s. 176-179). Wrocław: Ossolineum.

Czeżowski, T. (1989c). Sens i wartość życia (2). W: T. Czeżowski, Pisma z etyki i teorii wartości (s. 180-185). Wrocław: Ossolineum.

Elzenberg, H. (1991a). Aksjologiczne pojęcie sensu. W: H. Elzenberg, Z filozofii kultury (s. 338-353). Kraków: Znak.

Elzenberg, H. (1991b). Czy tak zwany sens może być życiu nadany? W: H. Elzenberg, Z filozofii kultury (s. 375-379). Kraków: Znak.

Hostyński, L. (1999). Układacz tablic wartości. Lublin: Wydawnictwo UMCS.

Kołakowski, L. (1957). Światopogląd i życie codzienne. W: L. Kołakowski, Światopogląd $i$ życie codzienne (s. 174-206). Warszawa: PIW.

Krąpiec, M.A. (1991). Ja-człowiek. Lublin: Redakcja Wydawnictw KUL.

Plessner, H. (1994). Władza a natura ludzka. Esej o antropologii światopoglądu historycznego. Tłum. E. Paczkowska-Łagowska. Warszawa: Wydawnictwo Naukowe PWN.

Przełęcki, M. (2002). Sens życia. W: M. Przełęcki, O rozumności i dobroci. Propozycje i moraty (s. 235-240). Warszawa: Semper.

Tatarkiewicz, W. (1962). O szczęściu. Warszawa: PWN.

Zwoliński, Z. (1974). Byt i wartość u Nicolaia Hartmanna. Warszawa: PWN.

\section{IS THE MEANING OF LIFE THE SAME AS THE PURPOSE OF LIFE? AXIOLOGICAL CONSIDERATIONS}

\section{Summary}

The aim of this text is to consider whether the meaning of life and purpose of life is the same. These philosophical investigations assume axiological objectivism, which claims two things: 1) values are a characters or qualities of objects, 2) phrases like ' $\mathrm{X}$ is good' are sentences in logical sense. As the main methods used in investigations was conceptual and linguistic analysis, which have been used to characterize 
the notion of 'life' and 'meaning'. This step allowed to precise notion of 'meaning of life' and allowed to consider the titled question. Result is negative: meaning of life is based on values, and not on arbitrarily taking purposes. If meaning of life is a some kind of essential good, then purposes cannot make life meaningful, if themselves are not valuable. 